\title{
$\alpha$-Tocopheryl succinate and TRAIL selectively synergise in induction of apoptosis in human malignant mesothelioma cells
}

\author{
M Tomasetti",', MR Rippo', R Alleva ${ }^{2}$, S Moretti', L Andera ${ }^{3}$, J Neuzil $^{4,5}$ and A Procopio' \\ 'Department of Molecular Pathology and Innovative Therapies, Polytechnic University of Marche, 60131 Ancona, Italy; ' ${ }^{2}$ Department of Anesthesiology, \\ IRCCS Istituti Ortopedici Rizzoli, 40100 Bologna, Italy; ${ }^{3}$ Institute of Molecular Genetics, Czech Academy of Sciences, 14000 Prague, Czech Republic; \\ ${ }^{4}$ Department of Pathology II, Faculty of Health Sciences, University Hospital, 58183 Linköping, Sweden; ${ }^{5}$ School of Health Sciences, \\ Griffith University Gold Coast Campus, Southport, 9726 Queensland, Australia
}

Malignant mesothelioma (MM) is a fatal type of neoplasia with poor therapeutic prognosis, largely due to resistance to apoptosis. We investigated the apoptotic effect of $\alpha$-tocopheryl succinate ( $\alpha$-TOS), a strong proapoptotic agent, in combination with the immunological apoptogen TNF-related apoptosis-inducing ligand (TRAIL) on both MM and nonmalignant mesothelial cells, since MM cells show low susceptibility to the clinically intriguing TRAIL. All MM cell lines tested were sensitive to $\alpha$-TOS-induced apoptosis, and exerted high sensitivity to TRAIL in the presence of subapoptotic doses of the vitamin E analogue. Neither TRAIL or $\alpha$-TOS alone or in combination caused apoptosis in nonmalignant mesothelial cells. Isobologram analysis of the cytotoxicity assays revealed a synergistic interaction between the two agents in MM cells and their antagonistic effect in nonmalignant mesothelial cells. TRAILinduced apoptosis and its augmentation by $\alpha$-TOS were inhibited by the caspase- 8 inhibitor Z-IETD-FMK and the pan-caspase inhibitor Z-VAD-FMK. Activation of caspase- 8 was required to induce apoptosis, which was amplified by $\alpha$-TOS via cytochrome $c$ release following Bid cleavage, with ensuing activation of caspase-9. Enhancement of TRAIL-induced apoptosis in MM cells by $\alpha$-TOS was also associated with upregulation of the TRAIL cognate death receptors DR4 and DR5. Our results show that $\alpha$-TOS and TRAIL act in synergism to kill MM cells via mitochondrial pathway, and are nontoxic to nonmalignant mesothelial cells. These findings are indicative of a novel strategy for treatment of thus far fatal MM.

British Journal of Cancer (2004) 90, 1644-1653. doi:I0.1038/sj.bjc.6601707 www.bjcancer.com

Published online 23 March 2004

(c) 2004 Cancer Research UK

Keywords: $\alpha$-tocopheryl succinate; TRAIL; synergism; apoptosis; malignant mesothelioma

Human malignant mesothelioma (MM) represents a tumour, which arises from mesothelial cells of the pleura or peritoneal cavities. The pathogenesis of this disease is associated with exposure to asbestos fibres (Mossman et al, 1996). Recently, Simian virus-40 (SV-40) has been associated with this malignancy (Carbone et al, 1994). The SV-40 oncogenic proteins bind and inactivate cellular p53 (Carbone et al, 1997) and the SV-40-positive status negatively affects the prognostic outcome of MM patients (Procopio et al, 2000). A typical feature of MM is its resistance to both chemotherapeutic agents and radiation (Houghton, 1999; Tomek et al, 2003). The general resistance of MM cells to apoptosis may explain the insensitivity of mesothelioma to therapy (Narasimhan et al, 1998), which has been shown for a variety of apoptotic agonists, although its mechanism has not been elucidated (Soini et al, 1999).

The immunological proapoptotic agent, tumour necrosis factorrelated apoptosis-inducing ligand (TRAIL, Apo2L) induces apoptosis in a wide variety of malignant cells without exhibiting

*Correspondence: Dr M Tomasetti, Dipartimento di Patologia Molecolare e Terapie Innovative, Università Politecnica delle Marche, via Ranieri I, Ancona, Italy; E-mail: mtomasetti@virgilio.it

Received 3 November 2003; revised 16 January 2004; accepted 19 January 2004; published online 23 March 2004 systemic toxicity to normal cells or tissues (French and Tschopp, 1999). The mechanism of TRAIL proapoptotic signalling includes its interaction with two death domain-containing receptors, DR4 (TRAIL-R1) and DR5 (TRAIL-R2). Although DR4 and DR5 are both widely expressed in human tissue, normal cells are usually resistant to TRAIL (Ashkenazi and Dixit, 1998). The reason may be that normal cells often express TRAIL decoy receptors (DcRs), DcR1 (TRAIL-R3) and DcR2 (TRAIL-R4), which compete with the death receptors (DRs) (Ashkenazi and Dixit, 1999). Based on the observations of an increase in DR5 expression by DNA-damaging agents that induce apoptosis in a p53-dependent manner (Wu et al, 1997), it has been suggested that TRAIL-dependent signalling may be related to p53 activation (Sheikh et al, 1998). Thus, agents capable of upregulating expression of TRAIL DRs are likely to enhance susceptibility of cells to TRAIL. Indeed, chemotherapeutic compounds like doxorubicine, 5-fluorouracil, and CPT-11 showed a synergy in apoptosis induction with TRAIL, and suppressed tumour growth in animal models (Gliniak and Le, 1999; Keane et al, 1999). These findings are consistent with the notion that cancer can be treated more efficiently by combination of agents with synergistic/additive activities.

Several groups have shown that a semisynthetic analogue of vitamin $\mathrm{E}, \alpha$-tocopheryl succinate ( $\alpha$-TOS), is a potent inducer of apoptosis in a variety of malignant cells (Yu et al, 1999; Yamamoto et al, 2000; Neuzil et al, 2001a), while being largely nontoxic to 
normal cells and tissues (Neuzil et al, 2001a; Weber et al, 2002). The apoptotic effect of $\alpha$-TOS involves lysosomal and mitochondrial destabilisation as well as caspase-3 activation (Alleva et al, 2001; Neuzil et al, 2001b). $\alpha$-Tocopheryl succinate-induced apoptosis may be amplified by protein kinase C (PKC) inhibition (Neuzil et al, 2001b). Recently, $\alpha$-TOS has been shown to exert antineoplastic activity and to promote tumour dormancy in preclinical models (Malafa and Neitzel, 2000; Weber et al, 2002). Finally, $\alpha$-TOS has been reported to sensitise resistant breast cancer cells to Fas killing ( $\mathrm{Yu}$ et al, 1999) as well as to cooperate with TRAIL in apoptosis induction in colon cancer cells and in colon carcinoma growth suppression (Weber et al, 2002).

Here we have investigated the effect of $\alpha$-TOS and TRAIL in MM cells to test their potential ability to cooperatively induce apoptosis. We show that MM cells are highly susceptible to $\alpha$ TOS, which synergises with TRAIL. Neither $\alpha$-TOS nor TRAIL alone or in combination showed toxicity to nonmalignant mesothelial cells; rather, the $\alpha$-TOS antagonised the nonmalignant cells to the effects of TRAIL. These findings support the emerging idea of the vitamin $\mathrm{E}$ analogue as a novel anticancer agent and/or adjuvant (Neuzil, 2002).

\section{MATERIALS AND METHODS}

\section{Reagents}

$\alpha$-Tocopheryl succinate, annexin V-FITC, low melting point agarose, agarose, (3-4,5-dimethylthiazol-2-yl)-2,5-diphenyltetrazolium bromide (MTT), and 4',6-diamino-2-phenylindole (DAPI) were purchased from Sigma (St Louis, MO, USA). Soluble human recombinant tumour necrosis factor-related apoptosis-inducing ligand (hrTRAIL) was prepared as described elsewhere (Plasilova et al, 2002). Anti-DR4, anti-DR5, and anti-DcR1 monoclonal IgG were obtained from Alexis Biochemicals (Lausen, Switzerland), and the anti-DcR2 polyclonal IgG from ProSci (Poway, CA, USA), anticytochrome $c$ and anti-Bid IgG were from Pharmigen (San Diego, CA, USA), anticaspase-8 monoclonal IgG from Upstate Biotechnology (Lake Placid, NY, USA), and anticaspase-9 polyclonal IgG from Santa Cruz (Santa Cruz, CA, USA). All primers for RT - PCR were obtained from Sigma Genosys (St Louis, MO, USA). The colorimetric substrates for caspase-8 (Ac-IETD-pNA) and caspase-9 (Ac-LEHD-pNA), the caspase- 8 inhibitor (Z-IETDFMK), and the pan-caspase inhibitor (Z-VAD-FMK) were purchased from Calbiochem (San Diego, CA, USA). Foetal Bovine Serum (FBS) was obtained from EuroClone (Paignton, UK). The plasmids harbouring the green fluorescent protein (GFP) and the red fluorescence protein (RFP), pGFP, and pDsRed1-N1, respectively, were obtained from BD Biosciences (Palo Alto, CA, USA).

\section{Cell culture}

The MM-B1 (biphasic), Meso-2 (sarcomatoid), and Ist-Mes (epithelioid) human MM cell lines were used (Pass et al, 1995). The nonmalignant mesothelial cell line, Met-5A (ATTC, Rockville, MD, USA), was used as a nonmalignant control. HeLa cells were obtained from ATCC and used as a positive control for the expression of TRAIL receptors. The cells were cultured in the RPMI-1640 medium supplemented with $2 \mathrm{mM}$ L-glutamine, $100 \mathrm{U} \mathrm{ml}^{-1}$ penicillin, $100 \mu \mathrm{g} \mathrm{ml}^{-1}$ streptomycin, and $10 \% \mathrm{FBS}$.

\section{Cytotoxicity and isobologram analysis}

MM cells were plated in 96-well flat-bottom tissue culture plate at $2.5 \times 10^{3}$ per well. The cells were allowed to attach overnight, and then incubated for $24 \mathrm{~h}$ with $\alpha$-TOS and hrTRAIL at $\leqslant 100 \mu \mathrm{M}$ and $\leqslant 10 \mu \mathrm{g} \mathrm{ml}^{-1}$, respectively. $\alpha$-Tocopheryl succinate was dissolved in ethanol and diluted in complete RPMI-1640 to the final concentration, and was added to cells at $0.1 \%\left(\mathrm{vv}^{-1}\right)$ of ethanol.
Cell viability were determined using MTT (Carmichael et al, 1987). Briefly, following exposure of cells, $10 \mu \mathrm{l}$ of MTT $\left(5 \mathrm{mg} \mathrm{m}^{-1}\right.$ in PBS) was added, and after incubation for $4 \mathrm{~h}$ at $37^{\circ} \mathrm{C}$, the medium was removed and combined with $200 \mu \mathrm{l}$ of $1 \%$ SDS. Absorbance was read at $550 \mathrm{~nm}$ using an ELISA plate reader and control absorbance was designed as $100 \%$, with percentage of it as a cell survival. Survival curves were generated for $\alpha$-TOS and hrTRAIL, and the $\mathrm{IC}_{50}$ values were determined. The effect of combination of the drugs on $\mathrm{MM}$ and nonmalignant mesothelial cells was estimated by using the isobologram evaluation (Tsai et al, 1989). Briefly, the cells were incubated with both agents added simultaneously to the cell culture medium at different concentrations, and the $\mathrm{IC}_{50}$ values for each drug in combination were calculated. Isobolograms were plotted at the individual $\mathrm{IC}_{50}$ values.

\section{Apoptosis detection}

Annexin V-FITC assay Apoptosis was quantified using the annexin V-FITC method, which detects phosphatidyl serine (PS) externalised in the early phases of apoptosis (Boersma et al, 1996). Briefly, cells were plated at $10^{5}$ per well in 24 -well plates. After an overnight incubation, cells were treated with $\alpha$-TOS $(30 \mu \mathrm{M})$ or hrTRAIL $\left(50 \mathrm{ng} \mathrm{ml}^{-1}\right)$ alone or in combination. Floating and attached cells were collected, washed twice with PBS, resuspended in $0.1 \mathrm{ml}$ binding buffer ( $10 \mathrm{~mm}$ HEPES, $140 \mathrm{~mm} \mathrm{NaCl}, 5 \mathrm{~mm} \mathrm{CaCl}{ }_{2}$, $\mathrm{pH}$ 7.4), incubated for $20 \mathrm{~min}$ at room temperature with $2 \mu \mathrm{l}$ annexin V-FITC, supplemented with $10 \mu$ l of propidium iodide (PI) $\left(10 \mu \mathrm{g} \mathrm{ml}^{-1}\right)$, and analysed by flow cytometry (Becton Dickinson, Rutherford, NJ, USA), using channel 1 for annexin V-FITC binding and channel 2 for PI staining.

Comet assay DNA fragmentation was analysed using the neutral comet assay (Kizilian et al, 1999). Cells were sandwiched between thin layers of agarose on a microscope slide, lysed at neutral $\mathrm{pH}$, electrophoresed, and stained with a silver dye. During electrophoresis, loops or pieces of DNA migrate away from the nuclear remnant to produce a shape with the visual characteristics of a comet. The comet assay can thus distinguish apoptotic from nonapoptotic cells on the basis of their characteristic DNA fragmentation pattern (Tomasetti et al, 2001).

\section{Western blotting}

Cells were treated as indicated and lysed in a buffer containing $1 \%$ Nonidet, $5 \mathrm{~mm}$ DTT, $150 \mathrm{~mm} \mathrm{NaCl}, 2 \mathrm{~mm}$ EDTA, $50 \mathrm{~mm}$ Tris- $\mathrm{HCl}$, $\mathrm{pH} 7.4$, and a cocktail of protease inhibitors, and stored at $-80^{\circ} \mathrm{C}$ until analysis. Cell extracts were mixed with the sample buffer containing $12 \mathrm{~mm}$ Tris- $\mathrm{HCl}, \mathrm{pH} 6.8,6 \%$ SDS, $10 \% \beta$-mercaptoethanol, $20 \%$ glycerol, and $0.03 \%$ bromophenol blue. Protein samples (100 $\mu \mathrm{g}$ per lane) were boiled for $5 \mathrm{~min}$ and electrophoresed in $12.5 \%$ polyacrylamide gels. Separated proteins were transferred onto a nylon membrane and blocked with 5\% skimmed milk in PBS containing $0.1 \%$ Tween-20 (PBS-T) for $1 \mathrm{~h}$ at room temperature. Immunodetection was performed overnight at $4{ }^{\circ} \mathrm{C}$ in PBS-T using anticaspase-8, anticaspase- 9 and anti-Bid IgG. After incubation with an HRP-conjugated secondary IgG (Amersham, London, UK), the blots were developed using ECL (Pierce, Rockford, IL, USA). Protein loading was corrected for $\beta$-actin.

\section{Caspase activity assay}

After $\alpha$-TOS $(30 \mu \mathrm{M})$ and/or hrTRAIL $\left(50 \mathrm{ng} \mathrm{ml}^{-1}\right)$ treatment, cells were harvested at different time points and lysed in the caspase lysis buffer ( $1 \%$ Nonidet, $5 \mathrm{~mm}$ DTT, $150 \mathrm{~mm} \mathrm{NaCl}, 2 \mathrm{~mm}$ EDTA, $50 \mathrm{~mm}$ Tris-HCl, $\mathrm{pH}$ 7.4) containing a cocktail of protease inhibitors. The cytosolic fraction $(10 \mu \mathrm{g}$ protein) was incubated at $37^{\circ} \mathrm{C}$ in the caspase reaction buffer ( $1 \%$ Nonidet, $100 \mathrm{~mm} \mathrm{NaCl}$, $10 \mathrm{~mm}$ DTT, $0.1 \mathrm{~mm}$ EDTA, $50 \mathrm{~mm}$ HEPES, $\mathrm{pH} 7.5$, and $10 \%$ 
glycerol), containing the specific colorimetric substrates for caspases, Ac-IETD- $p$ NA for caspase- 8 or Ac-LEHD- $p$ NA for caspase-9, in a total volume of $100 \mu \mathrm{l}$. Caspase activity was evaluated as cleavage of the substrate and monitored at $405 \mathrm{~nm}$ in an ELISA plate reader. Caspase activity rates were expressed as optical density (OD) per min, and normalised for protein.

\section{TRAIL receptor analysis}

Expression of TRAIL receptors (DR4, DR5, DcR1, DcR2) was evaluated by flow cytometry before and after treatment with $\alpha$-TOS $(30 \mu \mathrm{M})$. MM and Met-5A cells were seeded $24 \mathrm{~h}$ before the treatment in six-well plates at $3 \times 10^{5}$ per well. HeLa cells were used as a positive control. After $16 \mathrm{~h}$ of treatment, floating and attached cells were collected, washed twice with PBS, and incubated at $4{ }^{\circ} \mathrm{C}$ with antibodies against DR4, DR5, DcR1, and DcR2, followed by a secondary FITC-conjugated IgG, and the cells analysed by flow cytometry. Cytoplasmic expression of TRAIL receptors was assessed after cell permeabilisation. Briefly, cells were fixed in $4 \%$ formaldehyde in PBS for $30 \mathrm{~min}$, washed, permeabilised with a saponine solution $(0.02 \%$ saponine in PBS plus $1 \% \mathrm{FCS}$ ) for $30 \mathrm{~min}$, incubated with the antibodies as described above, and assessed by flow cytometry.

\section{RT - PCR analysis}

Total RNA was isolated from $10^{6} \mathrm{MM}$ and Met-5A cells before and after treatment with $30 \mu \mathrm{M} \alpha$-TOS, using Trizol (Life Technologies, Rockville, MD, USA), according to the manufacturer's protocol. The first-strand cDNA was synthesised using the GeneAmp RNA PCR kit (PerkinElmer Life Sciences, Boston, MA, USA). PCR analyses were performed in the final volume of $20 \mu \mathrm{l}$ of buffer containing $1 \mu \mathrm{l}$ of the retro-transcription product, all four dNTPs (150 $\mu \mathrm{M}$ each), $\mathrm{MgCl}_{2}(2 \mathrm{~mm}), 1 \mathrm{U}$ of Taq Gold polymerase (Roche Molecular Biochemicals, Basel, Switzerland), and each primer at $1 \mu \mathrm{m}$. The house-keeping gene $\beta$-actin was used as a loading control. The sequences of primers were as published elsewhere (Bernard et al, 2001).

\section{Immunocytochemistry}

The MM cells were placed overnight in $35-\mathrm{mm}$ dishes on poly-Llysine-coated glass coverslip. After $4 \mathrm{~h}$ of incubation with $\alpha$-TOS $(30 \mu \mathrm{M})$ or hrTRAIL $\left(50 \mathrm{ng} \mathrm{ml}^{-1}\right)$ separately or in combination, the cells were washed two times with PBS, fixed with freshly prepared $3 \%$ formaldehyde in PBS, and incubated with saponine solution (0.05\% saponine and $2 \%$ FCS in PBS). Cells were then incubated with mouse antihuman cytochrome $c$ IgG in saponine solution for $1 \mathrm{~h}$ at room temperature. FITC-conjugated, antimouse secondary IgG was added. The coverslips were mounted on glass slides with Vectashield (Vector Laboratories, Inc., Burlingame, CA 94010, USA) and viewed in a fluorescence microscope.

\section{Confocal microscope analysis}

Met-5A and MM-B1 cells were plated in a six-well plate at $2 \times 10^{5}$ and transiently transfected with pDsRed1-N1 harbouring RFP, and with GFP-expressing vector (pGFP) (BD Biosciences, Palo Alto, CA, USA), respectively. The transfection was carried out by using the GenePorter transfection reagent (Gene Therapy Systems, Inc. San Diego, CA, USA) following the manufacturer's instructions. Briefly, cells were incubated with $1 \mathrm{ml}$ of the serum-free medium DNA/GenePorter transfection reagent complex, which was prepared by mixing $2 \mu \mathrm{g}$ DNA with $0.5 \mathrm{ml}$ serum-free medium, and this was combined with $10 \mu \mathrm{l}$ of GenePorter transfection reagent mixed with $0.5 \mathrm{ml}$ serum-free medium, followed by $30 \mathrm{~min}$ incubation at room temperature. After $3 \mathrm{~h}$ of incubation with the transfection complex, cells were washed and cultured for $48 \mathrm{~h}$. The
Met-5A-RFP and MM-B1-GFP cells were mixed and adhered on poly-L-lysine-coated glass coverslips. The transfected Met-5A-RFP and MM-B1-GFP cells were treated for $12 \mathrm{~h}$ with hrTRAIL and $\alpha$ TOS at $50 \mathrm{ng} \mathrm{ml}^{-1}$ and $30 \mu \mathrm{M}$, respectively. The cells were washed two times with PBS, fixed with freshly prepared $3 \%$ formaldehyde in PBS, and the coverslip was mounted with Vectashield plus DAPI (Vector Laboratories, Burlingame, CA 94010, USA) and viewed in a confocal microscope (BioRad, MRC 1024, Hercules, CA, USA).

\section{Statistical analysis}

All experiments were conducted at least three times, and data are shown as mean \pm s.d. Significance was evaluated by the ANOVA repeated measure test. Data were considered statistically significant at $P<0.05$.

\section{RESULTS}

\section{$\alpha$-Tocopheryl succinate and TRAIL exert different toxicity towards MM and nonmalignant mesothelial cells}

Treatment of MM and nonmalignant mesothelial cell lines with $\alpha$ TOS results in dose-dependent cytotoxicity. Figure 1A shows viability curves of MM-B1, Meso-2, and Ist-Mes cell lines with $\mathrm{IC}_{50}$ values ranging from 34 to $38 \mu \mathrm{M}$ of $\alpha$-TOS (Table 1). The cells were relatively resistant to TRAIL-induced cell death; the viability curve reached a plateau at $0.5 \mu \mathrm{g} \mathrm{ml}^{-1}$, and, except for the MM-B1 cells with $40-50 \%$ of dead cells, MM cells did not exert more than
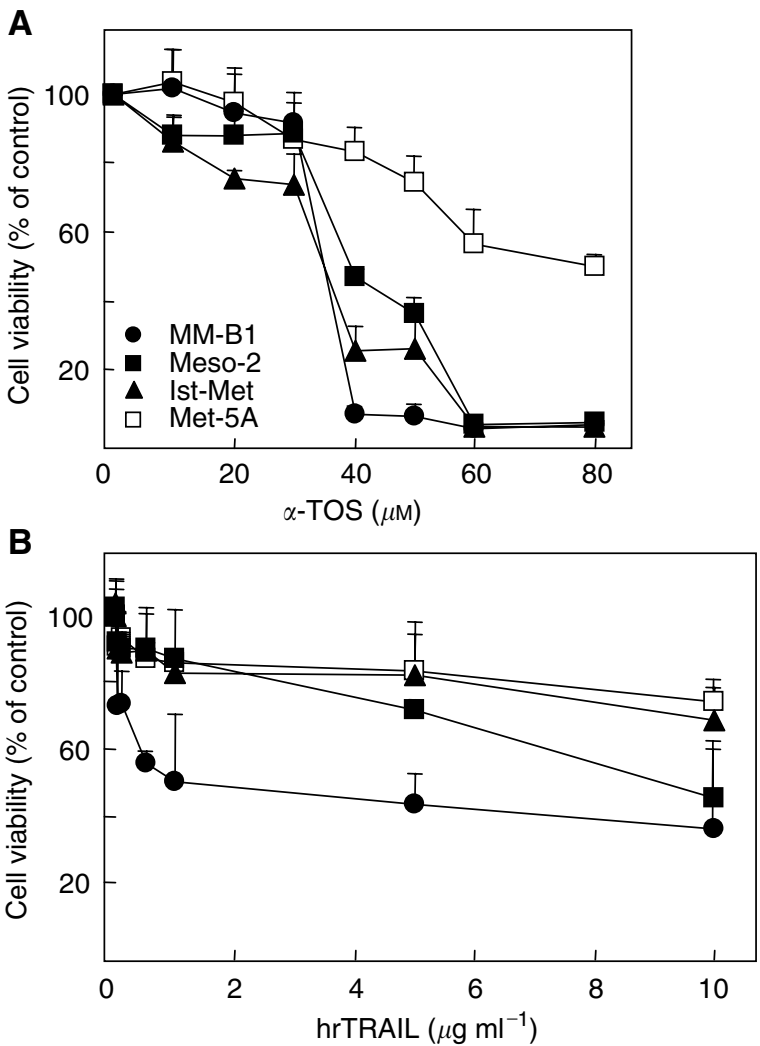

Figure I Cytotoxic effect of $\alpha$-TOS and hrTRAIL in MM and mesothelia cell lines. Cells were seeded into $96-$ well tissue culture plates $\left(2.5 \times 10^{3}\right.$ per well) and treated with increasing concentrations of $\alpha$-TOS $(\mathbf{A})$ and hrTRAIL (B). Survival curves for MM-BI, Meso-2, Ist-Mes, and Met-5A cell lines are based on the results of MTT assays after $24 \mathrm{~h}$ of drug exposure. All data are expressed as mean \pm s.d. from three independent experiments. 
Table I IC $\quad C_{50}$ values and killing efficacy of $\alpha$-TOS, hrTRAIL, and hrTRAIL plus $\alpha$-TOS in malignant mesothelioma and nonmalignant mesothelial cell lines

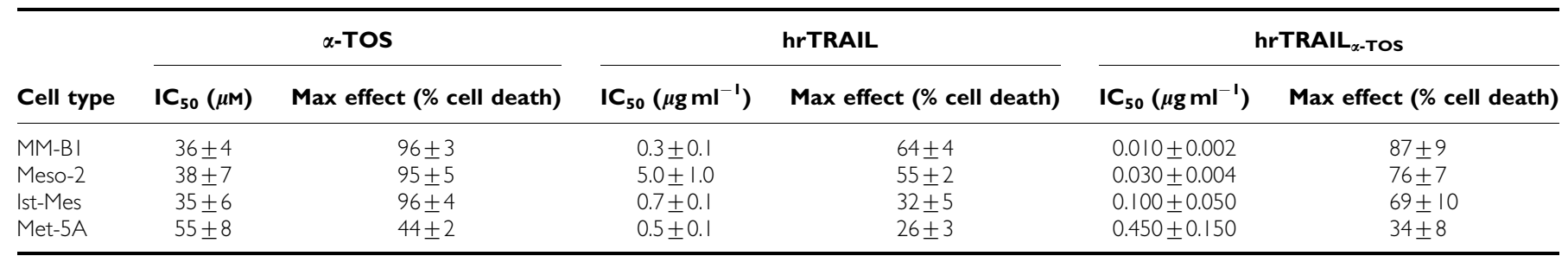

The $\mathrm{IC}_{50}$ values for $\alpha$-TOS, hrTRAIL, and hrTRAIL $\left(50 \mathrm{ng} \mathrm{ml}^{-1}\right)$ plus $\alpha$-TOS $(30 \mu \mathrm{M})$ were calculated from dose-response curves of MM and nonmalignant mesothelial cells at $24 \mathrm{~h}$ of treatment. Data are expressed as mean \pm s.d. from three independent experiments.

$10-15 \%$ cell death at pharmacologically relevant doses of TRAIL (Figure 1B, Table 1). Importantly, nonmalignant mesothelial cells (Met-5A) exhibited minimal toxicity in the presence of $\alpha$-TOS as well as hrTRAIL at concentrations of up to 80 and $10 \mu \mathrm{g} \mathrm{ml}^{-1}$, respectively (Figure $1 \mathrm{~A}$ and $\mathrm{B}$ ).

$\alpha$-Tocopheryl succinate and TRAIL show synergistic effect towards MM but antagonise each other in nonmalignant mesothelial cells

To investigate the effect of $\alpha$-TOS on TRAIL-induced cytoxicity, MM cells were exposed to increasing concentrations of individual drugs alone and in combination, cell viability was assessed and isobologram analysis performed. Isobolograms were created at the $\mathrm{IC}_{50}$ values as described elsewhere (Tsai et al, 1989). The $\mathrm{IC}_{50}$ unit values for $\alpha$-TOS $<1$ were plotted against corresponding IC $_{50}$ unit values for hrTRAIL; the distribution of points along the diagonal connecting the values of 1 suggests an additive effect of the two drugs while the points below or above the line indicate their synergism and antagonism, respectively (Figure 2). Thus, the effects of $\alpha$-TOS and hrTRAIL on cell death induction were synergistic in MM-B1 and Meso-2 cells and, to a lesser extent, in Ist-Mes cells where a synergistic/additive effect was observed. Notably, an antagonistic effect was found when the two drugs were combined in nonmalignant mesothelial cells, in which most of the points lie above the diagonal. Table 1 shows that the high $\mathrm{IC}_{50}$ values for TRAIL decreased by a factor of $\sim 10-$ 100 when $\alpha$-TOS was present at subapoptotic levels in the case of MM cells, while no effect was observed for Met-5A cells. Finally, $\alpha$-TOS enhanced TRAIL-induced apoptosis of MM cells in a dose- and time-dependent manner, while only marginal and nonsignificant apoptosis was observed in the nonmalignant mesothelial cells (Figure 3). We next attempted to directly show the selectivity of MM cells for synergistic effect of TRAIL and $\alpha$ TOS. For this, we transfected the Met-5A cells with a plasmid harbouring RFP, while MM-B1 cells with a GFP. The cells were then combined in culture and exposed to hrTRAIL plus $\alpha$-TOS. Figure 4 reveals that the combination of the two agents selectively induced apoptosis MM cells without affecting the nonmalignant mesothelial cells, since the DAPI-visualised nuclei were condensed in the 'green' malignant cells, whereas no nuclear morphological changes were observed in the 'red' nonmalignant cells ( $64 \pm 8 \mathrm{vs}$ $10 \pm 4 \%$ of apoptotic cells for MM-B1 and Met-5A, respectively). These observations directly document the intriguing paradigm of selective sensitisation of MM cells to TRAIL-dependent killing by $\alpha$-TOS.

\section{$\alpha$-Tocopheryl succinate differentially modulates expression of TRAIL receptors}

To explore the possibility that $\alpha$-TOS modulates TRAIL cytotoxicity by regulating expression of its receptors, we analysed the extent of TRAIL death and DcR expression at both mRNA and

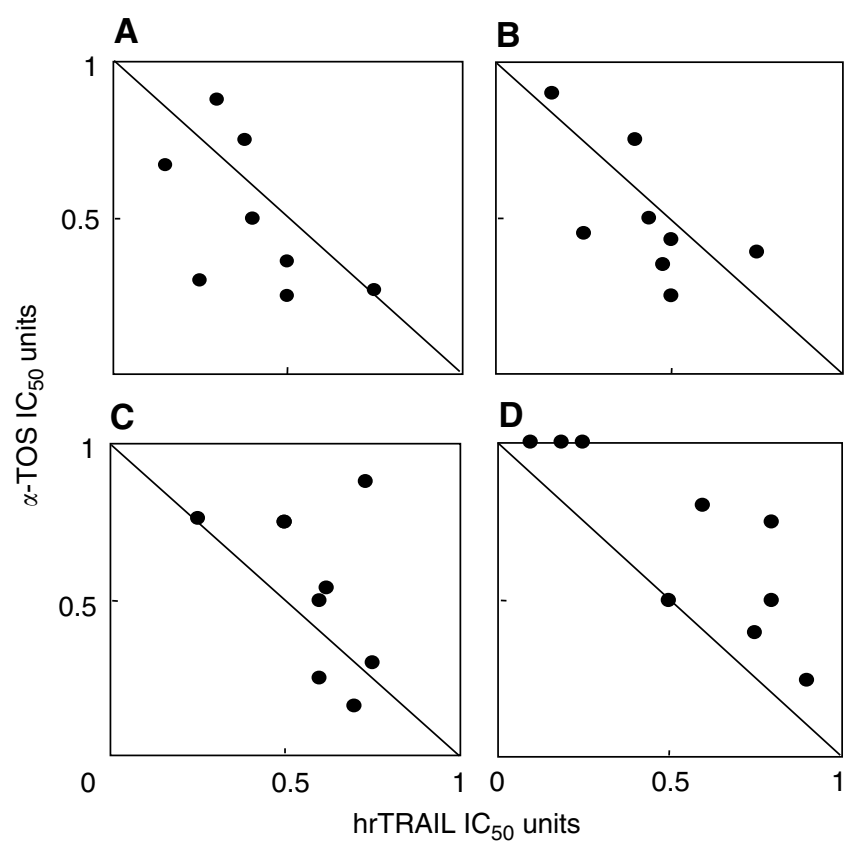

Figure 2 hrTRAIL and $\alpha$-TOS combination exhibit synergistic effects in MM cells and antagonise each other in nonmalignant mesothelial cells. The synergist/antagonistic effect of hrTRAIL and $\alpha$-TOS was evaluated by isobolograms at $\mathrm{IC}_{50}$ based on the results of $\mathrm{MTT}$ assays for $\mathrm{MM}-\mathrm{BI}(\mathbf{A})$, Meso-2 (B), Ist-Mes $(\mathbf{C})$, and Met-5A cells (D) treated with combinations of the two drugs. Each diagram combines the results at least of three independent experiments.

protein level. RT-PCR analysis shows that the expression of the DR4 and, in particular, DR5 mRNA was enhanced in MM cells treated with subapoptotic $(30 \mu \mathrm{M}) \alpha$-TOS (Figure $5 \mathrm{~A})$. On the other hand, the level of the expression of the DcR1 and DcR2 mRNA remained unchanged (data not shown). $\alpha$-TOS failed to modulate the level of expression of both death and DcR mRNA in Met-5A cells (Figure $5 \mathrm{~B}$ ). Time course analysis shows that exposure of MM cells to $\alpha$-TOS upregulated DR5 in a time-dependent manner, with a two-fold increase in DR5 mRNA at $4 \mathrm{~h}$ (Figure 5C), that is, at least $4 \mathrm{~h}$ before the detection of first signs of apoptosis (cf Figure 3B). Flow cytometric analysis, performed on both nonpermeabilised and permeabilised cells revealed that MM cells express both DR4 and DR5 protein on cell surface and in the cytoplasm (Figure 6A). DcR1 was not expressed in any of the cell lines tested, whereas DcR2 was detected only in the cytoplasmic compartment (Figure 6A). Sublethal doses of $\alpha$-TOS increased the expression of the DR4 and, more so, DR5 protein without affecting expression of the DcR1 and DcR2 protein (Figure 6A). The basal level of the DR4 and DR5 protein was lower in Met-5A cells then in 


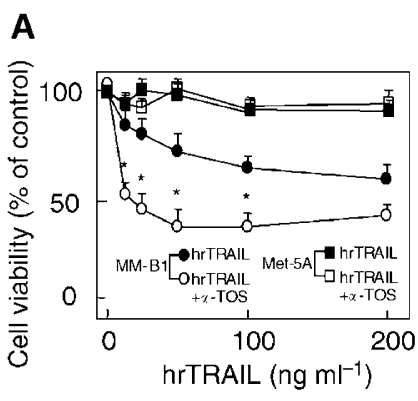

B

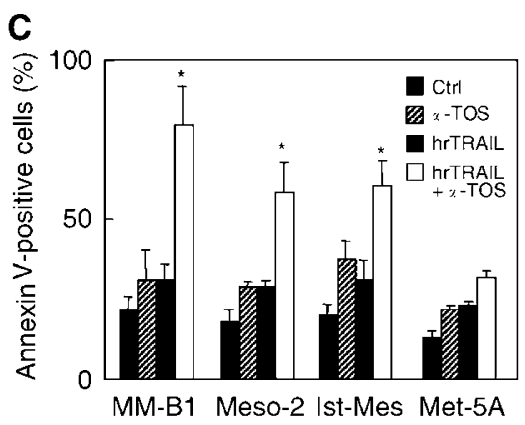

Figure 3 Effect of hrTRAlL, $\alpha$-TOS alone or their combination on apoptosis induction in MM cells. (A) MM-BI and Met-5A cells were exposed to increasing concentrations of hrTRAlL alone $\left(50 \mathrm{ng} \mathrm{ml}^{-1}\right)$ or in combination with a sublethal dose of $\alpha$-TOS $(30 \mu \mathrm{M})$ and their viability was assessed at $24 \mathrm{~h}$. (B) MM-Bl cells were exposed to $\mathrm{hrTRAIL}\left(50 \mathrm{ng} \mathrm{ml}^{-1}\right)$ or $\alpha$-TOS $(30 \mu \mathrm{M})$ alone or in combination at the indicated time points, and apoptosis was evaluated by annexin-V-FITC. (C) Mesothelioma (MM-BI, Meso-2, Ist-Mes) and mesothelial (Met-5A) cells were treated for $24 \mathrm{~h}$ with $50 \mathrm{ng} \mathrm{ml}^{-1}$ hrTRAIL, $30 \mu \mathrm{M} \alpha$-TOS, or $50 \mathrm{ng} \mathrm{ml}^{-1} \mathrm{hrTRAIL}$ plus $30 \mu \mathrm{M} \alpha$ TOS and evaluated for apoptosis. * The combined effect was significantly greater than the effects of individual agents, $P<0.05$. Results are expressed as mean \pm s.d. from three independent experiments. their malignant counterparts, whereas no expression of the DcR1 and DcR2 protein was detected in Met-5A cells (Table 2). Finally, Met-5A cells exposed to $\alpha$-TOS showed only a nonsignificant increase of the DR expression (Figure 6B, Table 2).

\section{$\alpha$-Tocopheryl succinate facilitates the TRAIL proapoptotic signalling}

TRAIL-induced apoptosis can be characterised by activation of caspases, including caspase- $8,-9$, and -3 , with their pattern of activation being cell type-dependent (Griffith et al, 1998). When MM cells were treated with TRAIL, caspase- 8 was transiently activated, as shown by increased protease activity at $4 \mathrm{~h}$ and by the procaspase cleavage as soon as at $1 \mathrm{~h}$ of incubation (Figure 7A and B). This activation of caspase- 8 at $4 \mathrm{~h}$ was correlated with only low levels of apoptosis (cf Figure $3 \mathrm{~B}$ and $\mathrm{C}$ ). Combined treatment with TRAIL and $\alpha$-TOS, which overcame resistance of MM cells to TRAIL, resulted in very low level of caspase- 8 activity, but promoted caspase- 9 activation (Figure $7 \mathrm{~A}$ and $\mathrm{B}$ ).

The link between caspase- 8 and -9 activation may be mediated by the proapoptotic cleavage of Bid. Indeed, combination of $\alpha$-TOS and TRAIL resulted in early (1-h) Bid cleavage, triggering the ensuing proapoptotic mitochondrial events, including the cytosolic mobilisation of cytochrome $c$ (Figure $8 \mathrm{~A}$ and B). Preincubation with the caspase- 8 inhibitor Z-IETD-FMK inhibited the synergistic effect of TRAIL and $\alpha$-TOS but not $\alpha$-TOS-induced apoptosis, while treatment with the pan-caspase inhibitor, Z-VAD-FMK, completely inhibited apoptosis in MM cells, regardless of the treatment regimen (Figure 9A and $\mathrm{B}$ ).

\section{DISCUSSION}

The aim of the study was to investigate the effect of combined treatment of MM cells with $\alpha$-TOS and TRAIL. As $\alpha$-TOS exerts its
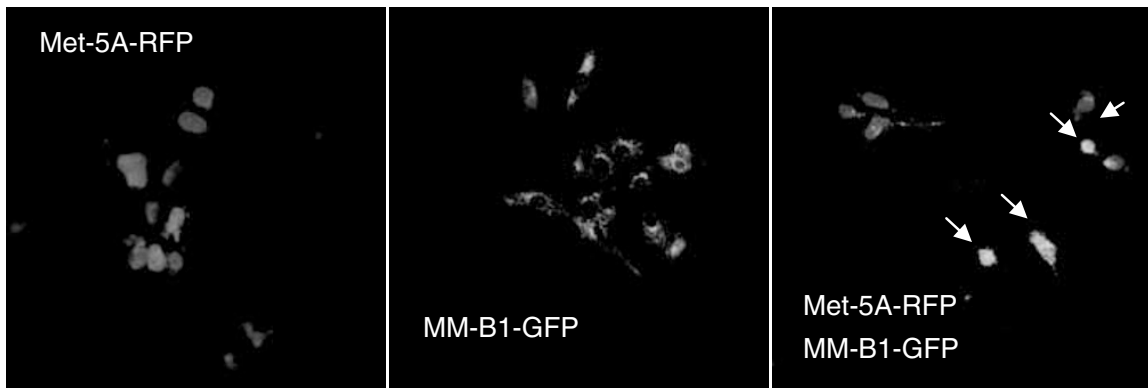

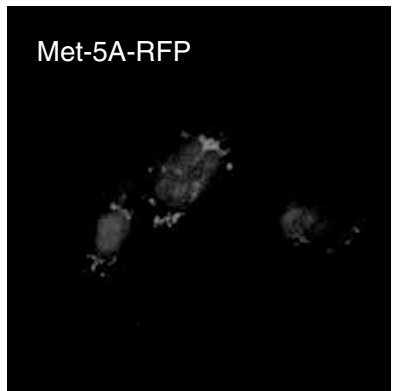

Control

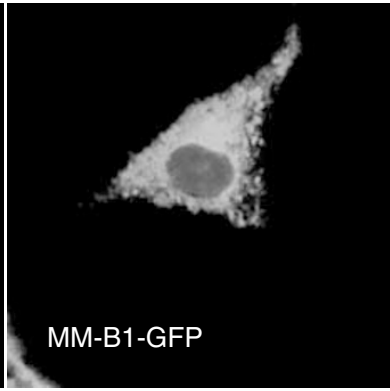

Control

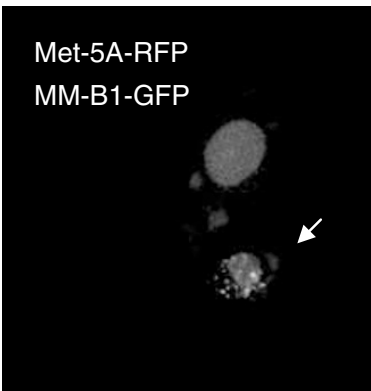

hrTRAIL $+\alpha-$ TOS

Figure 4 hrTRAIL and $\alpha$-TOS combination selectively induce apoptosis in MM cells. Met-5A and MM-BI were transiently transfected with pDsRed I-NI and pGFP, respectively. The transfected cells were combined and allowed to adhere to coverslips, and were treated for $12 \mathrm{~h}$ with $\mathrm{hrTRAIL}$ and $\alpha$-TOS at $50 \mathrm{ng} \mathrm{ml}^{-1}$ and $30 \mu \mathrm{M}$, respectively. The coverslips were then mounted in Vectashield plus DAPI and viewed in a confocal microscope. The hrTRAIL/ $\alpha$-TOS treatment induced nuclear condensation in the 'green' MM-BI-GFP cells (arrows), whereas no such nuclear morphological changes were observed in the 'red' Met-5A-RFP cells. 
A
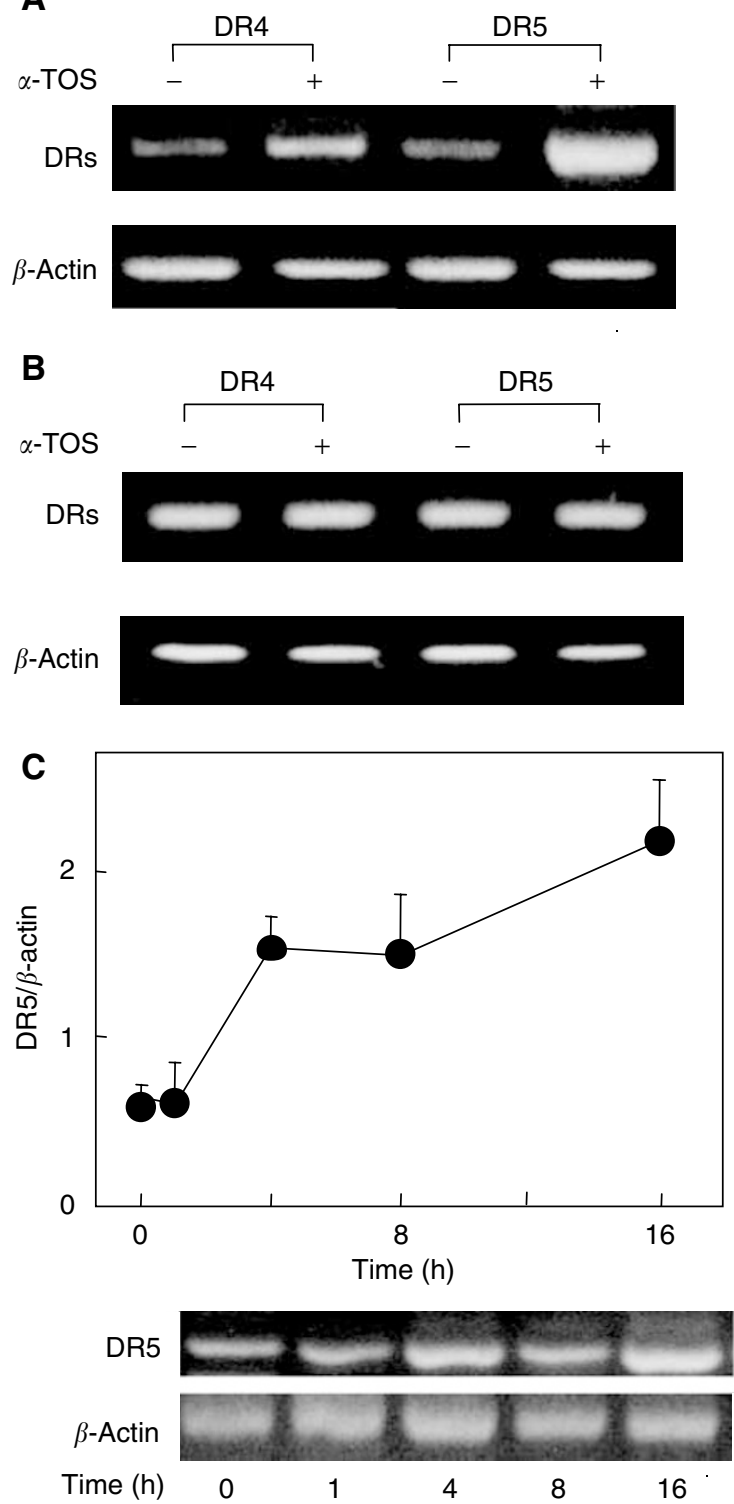

Figure 5 Effect of $\alpha$-TOS treatment on the expression of TRAIL receptors in MM and mesothelial cells. The death receptors (DR4, DR5) were evaluated in MM-BI $(\mathbf{A})$ and Met-5A cells $(\mathbf{B})$ as mRNA expression before and after treatment with $30 \mu \mathrm{M} \alpha$-TOS for $4 \mathrm{~h}$. (C) MM-BI cells were treated with $30 \mu \mathrm{M} \alpha$-TOS at the indicated time points, and mRNA expression of DR5 evaluated. Results in panels $(\mathbf{A})-(\mathbf{C})$ are representative of three independent experiments.

proapoptotic activity via the distal, mitochondrial route, and TRAIL-induced cell death is relayed via the proximal pathway, triggered by the cell surface receptor engagement, we hypothesised that the two different modes of action could potentiate apoptosis in the TRAIL-resistant MM cells. If so, TRAIL and the vitamin E analogue could represent interesting drugs for combinatorial treatment of MM, a thus far incurable neoplastic disease.

Our results herein clearly demonstrate a cross-talk between $\alpha$ TOS and TRAIL in several processes resulting in efficient apoptosis induction in MM cells. Thus, in all MM cell lines tested, $\alpha$-TOS was found to enhance TRAIL-induced cell death in a synergistic manner regardless of their phenotype ( $c f$ Figure 2 and 3), while MM cells exerted relative resistance to TRAIL alone at as much as $10 \mu \mathrm{g} \mathrm{ml}^{-1}$ of the agent. Important too, $\alpha$-TOS and TRAIL exerted
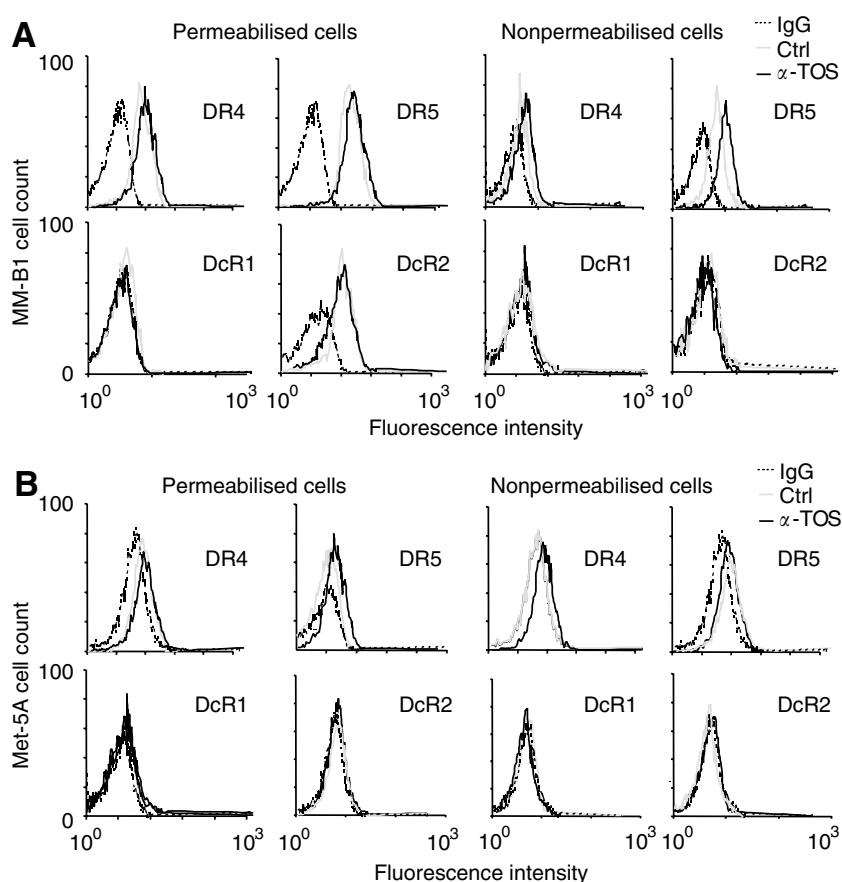

Figure 6 Cell surface expression of TRAIL receptors evaluated on permeabilised and nonpermeabilised MM and mesothelial cells after $\alpha$-TOS treatment. TRAIL receptor protein analysis was performed on MM-BI (A) and Met-5A (B) cells. Cells were seeded at $3 \times 10^{5}$ per well into six-well plates and exposed to $\alpha$-TOS for $16 \mathrm{~h}$. Permeabilised and nonpermeabilised cells were then incubated with antibodies against DR4, DR5, DcRI, or DcR2, and their expression was evaluated by flow cytometry. Results are representative of three independent experiments with similar results.

an antagonistic effect in case of nonmalignant mesothelial cells ( $c f$ Figure 2). This is a highly intriguing finding, since it points to the possibility that, if applied together, $\alpha$-TOS and TRAIL will efficiently and selectively kill MM cells while protecting the neighbouring nonmalignant mesothelial cells of the pleural or peritoneal cavity ( $c f$ Figure 4 ). This notion is consistent with reports showing protective activity of $\alpha$-TOS towards normal cells and tissues (Vuchetich et al, 1996; Zhang et al, 2001). The reason for this protective effect is, most likely, due to conversion of $\alpha$-TOS to $\alpha$-tocopherol $(\alpha-\mathrm{TOH})$, as shown, for example, for hepatocytes (Fariss et al, 2001). This is consistent with the notion that $\alpha$-TOS has a dual activity: as $\alpha$-TOS, the provitamin form, it causes apoptosis in malignant cells, thereby suppressing tumour growth, while as $\alpha-\mathrm{TOH}$, the vitamin form, it acts as an antioxidant protecting normal cells from insults such as inflammation (Neuzil, 2002).

The biphasic viability curve for MM cells treated with TRAIL ( $c f$ Figure 1B) indicates either the presence of two different cell populations, resistant and sensitive, or the development of resistance during treatment. Indeed, MM cells pretreated with TRAIL developed resistance against a second TRAIL exposure, reaching a maximum at $8 \mathrm{~h}$ and decaying after $24 \mathrm{~h}$ of incubation (Tomasetti et al, unpublished data), suggesting an intrinsic mechanisms of the cells for evading apoptosis. The presence of this resistant subpopulation may be due to initial activation of survival pathways (Ehrhardt et al, 2003), and $\alpha$-TOS may sensitise the resistant cells by interfering with these pathways (Neuzil, 2002).

A cooperative proapoptotic effect of $\alpha$-TOS with immunological apoptogens has been observed in breast cancer (Yu et al, 1999) and colon cells (Weber et al, 2002). The former report showed that $\alpha$ TOS converted the Fas-resistant to Fas-sensitive cells via mobilisation of the Fas receptor from the cytosol to the plasma 
Table 2 Evaluation of cell surface expression of TRAIL receptors before and after $\boldsymbol{\alpha}$-TOS treatment in MM and mesothelial cells

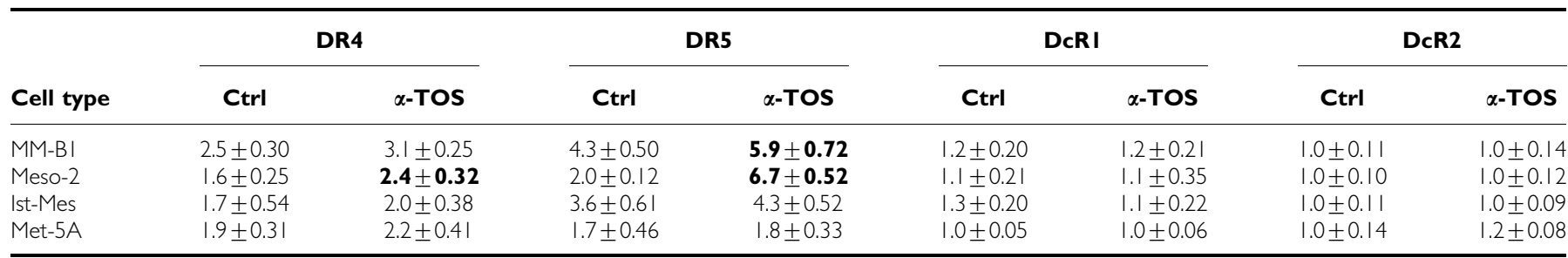

The expression of TRAIL receptors was evaluated by flow cytometry before (Ctrl) and after treatment with $\alpha$-TOS (30 $\mu$ M, I6 h) in MM and mesothelial cells. The values represent the fluorescence intensity of the receptors normalised for a blank incubated with an irrelevant primary antibody. Data are expressed as mean \pm s.d. from three independent experiments and statistical differences between controls vs $\alpha$-TOS treatment are bold, $P<0.005$.

A
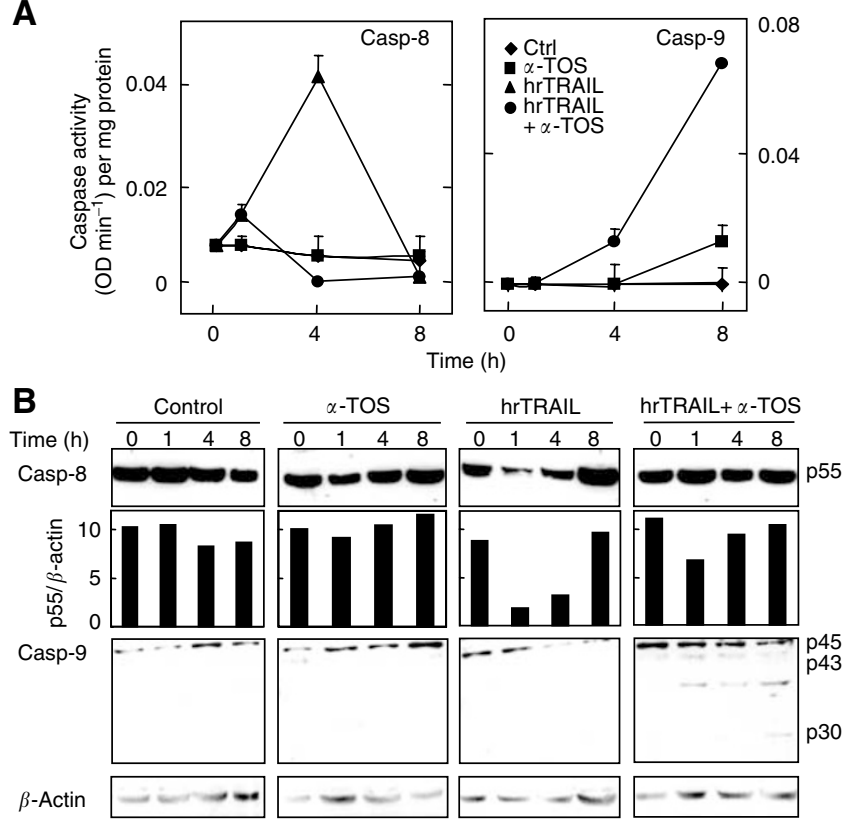

Figure 7 Activation of caspase- 8 and -9 by hrTRAlL and $\alpha$-TOS alone or by their combination in MM cells. MM-BI cells were treated with $50 \mathrm{ng} \mathrm{ml}^{-1}$ hrTRAIL, $30 \mu \mathrm{M} \alpha$-TOS, or $50 \mathrm{ng} \mathrm{ml}^{-1}$ hrTRAIL plus $30 \mu \mathrm{M} \alpha$ TOS, the activity of caspase- 8 and -9 , expressed as OD/min per mg protein (A), or caspase-8 and -9 cleavage (B), were assessed at the indicated time points. Data are expressed as mean \pm s.d. from three independent experiments

membrane. Thus, enhancement of DR expression on cell surface could enhance cancer surveillance. We show here that higher expression of TRAIL DRs, in particular DR5, by $\alpha$-TOS on the surface of MM cells was due to de novo synthesis rather than translocation of TRAIL receptors from cytoplasm to the plasma membrane ( $c f$ Figure 6). It has been reported previously that cells can be sensitised to TRAIL by upregulation of DR5 in response to activation of the transcription factor $\mathrm{p} 53$, suggesting that enhanced DR5 expression may be a common mechanism for apoptosis induction by DNA-damaging agents (Wu et al, 1997). We have recently observed that exposure of cancer cells to $\alpha$-TOS results in early generation of reactive oxygen species (ROS) (Weber et al, 2003), and we have also observed phosphorylation of p53 (Tomasetti et al, unpublished data). It is thus feasible that a p53mediated process contributes to $\alpha$-TOS-induced DR5 upregulation in MM cells, consistent with another report suggesting p53 activation as a mode of sensitisation of cancer cells towards TRAIL killing (Xie et al, 2001). Although Met-5A cells, used here as a control cell line, are immortalised with SV-40 resulting in inactivation of p53, translocation of p53 into the nucleus was also

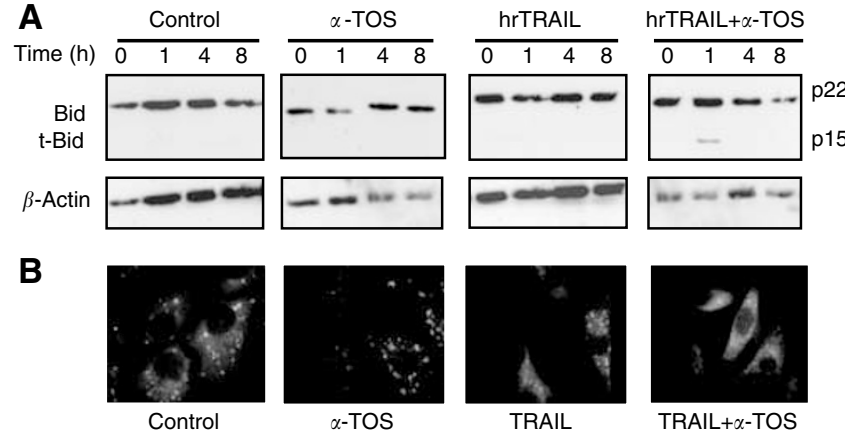

Figure 8 Drug combination determines Bid cleavage and cytochrome $c$ release. MM-BI cells were treated with $50 \mathrm{ng} \mathrm{ml}^{-1}$ hrTRAIL, $30 \mu \mathrm{M} \alpha$-TOS, or $50 \mathrm{ng} \mathrm{ml}^{-1}$ hrTRAIL plus $30 \mu \mathrm{M} \alpha$-TOS, Bid cleavage $(\mathbf{A})$ and cytochrome $c$ released from mitochondria (B) were assessed. Picture shown is representative for at least two independent experiments.

observed in these cells following $\alpha$-TOS treatment (unpublished data). However, p53 activation results in a small increase of DRs expression in Met-5A, contrary to that observed in MM cell lines. Since we have also found that exposure of cells to $\alpha$-TOS leads to very fast activation of sphingomyelinase resulting in early accumulation of ceramide (Weber et al, 2003), which has been suggested to upregulate DRs (Herr et al, 1999), additional/ alternative mechanisms cannot be ruled out, including modulation of expression of bcl-2 family proteins (Ray and Almasan, 2003). However, we observed that upregulation of DRs is not followed by an increase of caspase- 8 activity suggesting that other mechanisms are involved in the synergistic $\alpha$-TOS/TRAIL MM cell killing.

Kinetics analysis of TRAIL-induced signalling revealed a transient activation of caspase-8, which resulted in induction, albeit low, of apoptosis. Caspase-8 activation was less pronounced in the presence of TRAIL plus $\alpha$-TOS. Under this setting, we observed activation of the mitochondria-dependent apoptotic pathway, including Bid cleavage, cytochrome $c$ cytosolic mobilisation and, finally, caspase- 9 activation. Bid cleavage may lead to mitochondrial translocation of Bax, as shown for $\alpha$-TOS in other cancer models (Weber et al, 2003; Yu et al, 2003). Preincubation of MM cells with the caspase-8 inhibitor Z-IETD-FMK inhibited the synergistic effect of TRAIL and $\alpha$-TOS, while treatment with the pan-caspase inhibitor Z-VAD-FMK completely inhibited apoptosis initiated by the two inducers alone or in combination. These results clearly document that caspase-8 activation is essential for the TRAIL-dependent effect, and that this is significantly amplified by activation of caspase- 9 in the presence of subapoptotic levels of $\alpha$-TOS. Thus, there is a cross-talk between $\alpha$-TOS and TRAIL in potentiation of apoptotis in the TRAIL-resistant MM cells, in particular in linking the receptor- and mitochondria-associated events. 

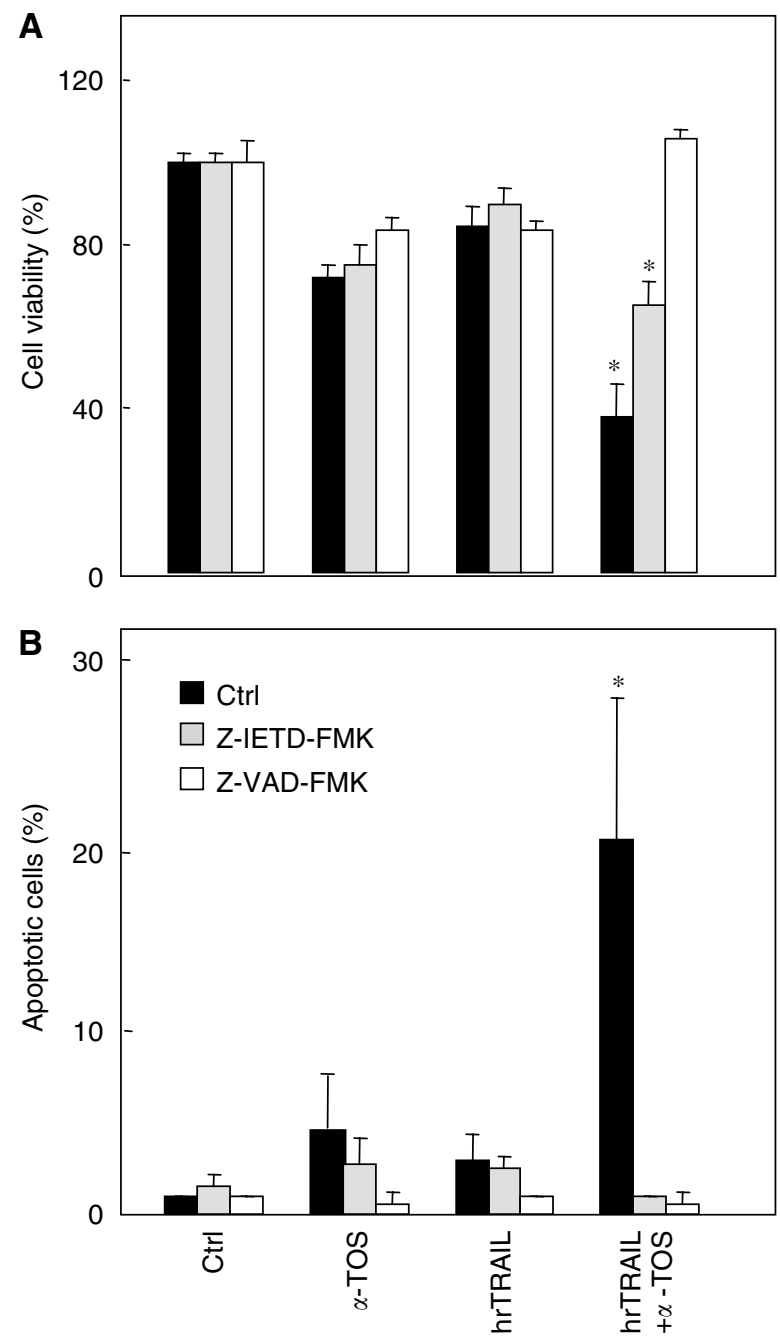

Figure 9 Caspase inhibitors suppress the synergism of hrTRAlL and $\alpha$ TOS. MM-BI cells were treated with $50 \mathrm{ng} \mathrm{ml}^{-1}$ hr-TRAIL, $30 \mu \mathrm{M} \alpha$-TOS, or $50 \mathrm{ng} \mathrm{ml}^{-1} \mathrm{hr}$-TRAIL plus $30 \mu \mathrm{M} \alpha$-TOS, in the absence or presence of the caspase-8 inhibitor Z-IETD-FMK or the pan-caspase inhibitor Z-VADFMK, and evaluated for cell viability by MTT analysis $(\mathbf{A})$ or apoptosis by the comet assay $(\mathbf{B})$. The symbol '*' indicates statistical differences $(P<0.05)$ in the values for cells treated with $\alpha$-TOS and hrTRAIL alone and those cotreated with the two agents. Data are expressed as mean \pm s.d. from three independent experiments.

Our data suggest that cleavage of Bid may be considered as the link between the proximal and distal apoptotic signalling pathways. A similar scenario for a cross-talk between the two routes has been suggested by others. Thus, cleavage of Bid is involved in sensitisation to TRAIL of colorectal (Lacour et al, 2001; Ravi and Bedi, 2002) and prostate cancer cells (Nimmanapalli et al, 2001). These reports show an increased activity of caspase- 8 associated with the sensitisation, suggesting the type II cells, that is, cells where receptor-mediated proapoptotic signalling is transmitted downstream via Bid cleavage following the death-inducing signalling complex (DISC) formation on the cytosolic terminus of the DRs (Ashkenazi and Dixit, 1998). However, our observations with MM cells point to Bid cleavage at minimal caspase-8 activation in the presence of TRAIL and $\alpha$-TOS, while TRAIL alone, causing higher activation of caspase-8, is inefficient in apoptosis induction and Bid cleavage does not occur. Therefore, there appears to be a block in the type I signalling in MM cells downstream from caspase- 8 to the effector caspases, and a crosstalk between $\alpha$-TOS and TRAIL, causing Bid cleavage resulting in mitochondrial signalling that then culminates in efficient apoptosis. Thus, MM cells, from the point of view of apoptotic signalling, may represent atypical type II cells (Scaffidi et al, 1998), possibly consistent with their general resistance to apoptosis, causing mesotheliomas incurable.

Taken together, we report that sublethal doses of $\alpha$-TOS selectively enhance TRAIL-dependent apoptotic signalling in MM via mitochondrial pathways, while antagonising the activity of TRAIL in nonmalignant mesothelial cells. The observed sensitisation of MM cells to TRAIL killing is associated with increased expression of DR4 and DR5, and with activation of the mitochondrial proapoptotic signalling with Bid cleavage linking the proximal and distal events, although the precise contribution of the parallel/auxiliary pathways to the overall efficacy of apoptosis execution in MM cells is not known at present. The importance of activation of both types of signalling in sensitisation of cancer cells to TRAIL has been recently shown for prostate cancer cells (Ray and Almasan, 2003). Our findings are in accord to those of Liu et al, 2001, reporting that sensitisation of MM cells toward TRAIL by chemotherapeutic is dependent on the mitochondrial pathway, in a c-Jun N-terminal kinase (JNK)dependent manner (Vivo et al, 2003). Thus, $\alpha$-TOS, although also acting via the JNK pathway (Yu et al, 2001) signalling downstream through Bax (Lei et al, 2002), promotes the receptor-dependent pathway, thereby maximizing the apoptotic potential of the cell. In conclusion, our data show that $\alpha$-TOS efficiently potentiates TRAIL killing of MM cells that are highly resistant to established treatment via mitochondrial mechanisms, and prompt testing of TRAIL and $\alpha$-TOS, as well as other vitamin E analogues (Birringer et $a l, 2003)$, in preclinical models of MM. The potential combinatorial clinical use of $\alpha$-TOS and TRAIL is supported by our recent findings that the vitamin $\mathrm{E}$ analogue promotes survival of immunocompromised mice with experimental peritoneal mesothelioma (Tomasetti et al, in press).

\section{ACKNOWLEDGEMENTS}

This work was supported by grants AIRC (Associazione Italiana per la Ricerca del Cancro), FIRC, COFIN 2002 from Ministero della Sanità, MIUR (Ministero dell'Istruzione, dell'Università e della Ricerca) to $\mathrm{AP}$ and by grants 83081030 from the University of Linköping and the Dust Diseases Board of Australia to JN, and grants A5052001 (GA AS CR) and LN00A026 (Center of Molecular and Cellular Immunology) to LA. We thank Dr John Eaton for his expert advise and Simone Bellagamba for help with confocal microscopy.

\section{REFERENCES}

Alleva R, Tomasetti M, Andera L, Gellert N, Borghi B, Weber C, Murphy MP, Neuzil J (2001) Coenzyme Q blocks biochemical but not receptormediated apoptosis by increasing mitochondrial antioxidant protection. FEBS Lett 503: $46-50$

Ashkenazi A, Dixit VM (1998) Death receptors: signalling and modulation. Science 281: 1305-1308

Ashkenazi A, Dixit VM (1999) Apoptosis control by death and decoy receptors. Curr Opin Cell 11: 255-260 
Bernard D, Quatannens B, Vandenbunder B, Abbadie C (2001) Rel/NF- $\kappa$ B transcription factors protect against tumor necrosis factor (TNF)-related apoptosis-inducing ligand (TRAIL)-inducing apoptosis by up-regulating the TRAIL decoy receptor DcR1. J Biol Chem 276: 27322-27328

Birringer M, EyTina JH, Salvatore BA, Neuzil J (2003) Vitamin E analogs as inducers of apoptosis: structure-function relationship. $\mathrm{Br} J$ Cancer 88: 1948 - 1955

Boersma AWM, Nooter K, Oostrum RG, Stoter G (1996) Quantification of apoptotic cells with fluoroscein isothiocyanate-labeled annexin $\mathrm{V}$ in Chinese hamster ovary cell cultures treated with cisplatin. Cytometry 24: $123-130$

Carbone M, Pass HI, Rizzo P, Martinetti MR, Di Muzio M, Mew DIY, Levine AS, Procopio A (1994) Simian Virus 40-like sequences in human pleural mesothelioma. Oncogene 9: 1781-1790

Carbone M, Rizzo P, Grimley PM, Procopio A, Mew DJ, Shridhar V, de Bartolomeis A, Esposito V, Giuliano MT, Steinberg SM, Levine AS, Giordano A, Pass HI (1997) Simian Virus-40 large-T antigen bind p53 in human mesotheliomas. Nat Med 3: 908-912

Carmichael J, DeGraff WG, Gazdar AF, Minna JD, Mitchell JB (1987) Evaluation of a tetrazolium-based semiautomated colorimetric assay: assessment of radiosensitivity. Cancer Res 47: 943-946

Ehrhardt H, Fulda S, Schmid I, Hiscott J, Debatin KM, Jeremias I (2003) TRAIL induced survival and proliferation in cancer cells resistant towards TRAIL-induced apoptosis mediated by NF- $\kappa$ B. Oncogene 22: $3842-3852$

Fariss MW, Nicholls-Grzemski FA, Tirmenstein MA, Zhang JG (2001) Enhanced antioxidant and cytoprotective abilities of vitamin E succinate is associated with a rapid uptake advantage in rat hepatocytes and mitochondria. Free Radical Biol Med 31: 530-541

French LE, Tschopp J (1999) The TRAIL to selective tumor death. Nat Med 5: $146-147$

Gliniak B, Le T (1999) Tumor necrosis factor-related apoptosis-inducing ligand's anti-tumor activity in vivo is enhanced by the chemotherapeutic agent CPT-11. Cancer Res 59: 6153-6158

Griffith TS, Chin WA, Jackson GC, Lynch DH, Kubin MZ (1998) Intacellular regulation of TRAIL-induced apoptosis in human melanoma cells. $J$ Immunol 161: 2833-2840

Herr I, Martin-Villalba A, Kurz E, Roncaioli P, Schenkel J, Cifone MG, Debatin KM (1999) FK506 prevents stroke-induced generation of ceramide and apoptosis signalling. Brain Res 826: 210-219

Houghton JA (1999) Apoptosis and drug response. Curr Opin Oncol 11: $475-481$

Keane MM, Ettemberg SA, Nau MM, Russel EK, Lipkowitz S (1999) Chemotherapy augments TRAIL-induced apoptosis in breast cell lines. Cancer Res 59: 734-741

Kizilian N, Wilkins RC, Reinhardt P, Ferrarotto C, McLean JR, McNamee JP (1999) Silver-stained comet assay for detection of apoptosis. Biotechniques 27: $926-930$

Lacour S, Hammann A, Wotawa A, Corcos L, Solary E, Dimanche-Boitrel MT (2001) Anticancer agents sensitize tumor cells to tumor necrosis factor-related apoptosis-inducing ligand-mediated caspase-8 activation and apoptosis. Cancer Res 61: 1645-1651

Lei K, Nimnual A, Zong WX, Kennedy NJ, Flavell RA, Thompson CB, BarSagi D, Davis RJ (2002) The Bax subfamily of Bcl2-related proteins is essential for apoptotic signal transduction by c-Jun $\mathrm{NH}_{2}$-terminal kinase. Mol Cell Biol 22: 4929-4942

Liu W, Bodle E, Chen JY, Gao M, Rosen GD, Broaddus VC (2001) Tumor necrosis factor-related apoptosis-inducing ligand and chemotherapy cooperate to induce apoptosis in mesothelioma cell lines. Am J Respir Cell Mol Biol 25: 111-118

Malafa MP, Neitzel LT (2000) Vitamin E succinate promotes breast cancer tumor dormancy. J Surg Res 93: 163-170

Mossman BT, Kamp DW, Weitzman SA (1996) Mechanisms of carcinogenesis and clinical features of asbestos-associated cancers. Cancer Invest 14: $466-480$

Narasimhan SR, Yang L, Gerwin BI, Broaddus VC (1998) Resistance of pleura mesothelioma cell lines to apoptosis: relation to expression of Bcl2 and Bax. Am J Physiol 275: L165-L171

Neuzil J (2002) Tocopheryl succinate epitomizes a compound with a shift in biological activity due to pro-vitamin-to-vitamin conversion. Biochem Biophys Res Commun 293: 1309-1313

Neuzil J, Weber T, Gellert N, Weber C (2001a) Selective cancer cell killing by $\alpha$-tocopheryl succinate. $B r$ J Cancer 84: $87-89$

Neuzil J, Weber T, Schroeder A, Lu M, Ostermann G, Gellert N, Mayne GC, Olejnicka B, Negre-Salvayre A, Sticha M, Coffey RJ, Weber C (2001b)
Induction of cancer cell apoptosis by $\alpha$-tocopheryl succinate: molecular pathway and structural requirements. FASEB J 15: 403-415

Nimmanapalli R, Perkins CL, Orlando M, O’Bryan E, Nguyen D, Bhalla KN (2001) Pretreatment with paclitaxel enhances apo-2 ligand/tumor necrosis factor-related apoptosis-inducing ligand-induced apoptosis of prostate cancer cells by inducing death receptors 4 and 5 protein levels. Cancer Res 61: 759-763

Pass HI, Stevens EJ, Oie H, Tsokos MG, Abati AD, Fetsch PA, Mew DJ, Pogribniak HW, Matthews, WJ (1995) Characteristics of nine newly derived mesothelioma cell line. Ann Thorac Surg 59: 835-844

Plasilova M, Zivny J, Jelinek J, Neuwirtova R, Cermak J, Necas E, Andera L, Stopka T (2002) TRAIL (Apo 2L) suppressed growth of primary human leukaemia and myelodysplasia progenitors. Leukemia 16: 67-73

Procopio A, Strizzi L, Vianale G, Betta P, Puntoni R, Fontana VV, Tassi G, Gareri F, Mutti L (2000) Simian Virus-40 sequences are negative prognostic cofactor in patients with malignant pleural mesothelioma. Genes Chromosomes Cancer 290: 173-179

Ravi R, Bedi A (2002) Requirement of BAX for TRAIL/Apo2L-induced apoptosis of colorectal cancers: synergism with sulindac-mediated inhibition of Bcl- $\mathrm{x}_{\mathrm{L}}$. Cancer Res 62: 1583-1587

Ray S, Almasan A (2003) Apoptosis induction in prostate cancer cells and xenografts by combined treatment with Apo2 ligand/tumor necrosis factor-related apoptosis-inducing ligand and CPT-11. Cancer Res 63: $4713-4723$

Scaffidi C, Fulda S, Srinivasan A, Friesen C, Li F, Tomaselli KJ, Debatin KM, Krammer PH, Peter ME (1998) Two CD95 (APO-1/Fas) signalling pathways. $E M B O$ J 17: 1675-1687

Sheikh MS, Burns TF, Huang Y, Wu GS, Amundson S, Brooks KS, Fornace AJ, el-Deiry WS (1998) p53-dependent and -independent regulation of the death receptor KILLER/DR5 gene expression in response to genotoxic stress and tumor necrosis factor- $\alpha$. Cancer Res 58: $1593-1598$

Soini Y, Kinnula V, Kaarteenaho-Wiik R, Kurttila E, Linnainmaa K, Paakko $\mathrm{P}$ (1999) Apoptosis and expression of apoptosis regulating proteins bcl-2, mcl-1, bcl-x, and bax in malignant mesothelioma. Clin Cancer Res 5: $3508-3515$

Tomasetti M, Alleva R, Borghi B, Collins AR (2001) In vivo supplementation with coenzyme Q10 enhances the recovery of human lymphocytes from oxidative DNA damage. FASEB J 15: 1425-1427

Tomasetti M, Gellert N, Procopio A, Neuzil J (2004) A vitamin E analogue supresses malignant mesothelioma in a preclinical model: a future drug against a fatal neoplastic disease? Int J cancer (in press)

Tomek S, Emri S, Krejcy K, Manegold C (2003) Chemotherapy for malignant pleural mesothelioma: past results and recent development. $\mathrm{Br}$ J Cancer 88: $167-174$

Tsai CM, Gazdar AF, Venzon DJ, Steiaberg SM, Dedrick RL, Mulshine JL, Kramer BS (1989) Lack of in vivo synergy between etoposide and cisdiamine-dichloroplatinum (II). Cancer Res 49: 2390-2397

Vivo C, Liu W, Broaddus VC (2003) c-Jun N-terminal kinase contributes to apoptotic synergy induced by tumor necrosis factor-related apoptosisinducing ligand plus DNA damage in chemoresistant, p53 inactive mesothelioma cells. J Biol Chem 278: 25461 - 25467

Vuchetich PJ, Bagchi D, Bagchi M, Hassoun EA, Tang L, Stohs SJ (1996) Naphthalene-induced oxidative stress in rats and the protective effects of vitamin E succinate. Free Radicals Biol Med 21: 577-590

Weber T, Dalen H, Andera L, Nègre-Savayre A, Augè N, Sticha M, Loret A, Terman A, Witting P, Higuchi M, Plasilova M, Zivny J, Gallert N, Weber C, Neuzil J (2003) Mitochondria play a central role in apoptosis induced by $\alpha$-tocopheryl succinate, an agent with anti-neoplastic activity: comparison with receptor-mediated pro-apoptotic signalling. Biochemistry 42: 4277-4291

Weber T, Lu M, Andera L, Lahm H, Gellert N, Fariss MW, Korinek V, Sattler W, Ucker DS, Terman A, Schröder A, Erl W, Brunk U, Coffey RJ, Weber C, Neuzil J (2002) Vitamin E succinate is a potent novel antineoplastic agent with high tumor selectivity and cooperativity with tumor necrosis factor-related apoptosis-inducing ligand (Apo2 ligand) in vivo. Clin Cancer Res 8: 863-869

Wu GS, Burns TF, McDonald ER, Jiang W, Meng R, Krantz ID, Kao G, Gan DD, Zhou JY, Muschel R, Hamilton SR, Spinner NB, Markowitz S, Wu G, El-Deiry WS (1997) KILLER/DR5 is a DNA damage-inducible p53regulated death receptor gene. Nat Genet 17: 141-143

Xie S, Wang Q, Wu H, Cogswell J, Lu L, Jhanwar-Uniyal M, Dai W (2001) Reactive oxygen species-induced phosphorylation of p53 on serine 20 is mediated in part by polo-like kinase-3. J Biol Chem 276: $36194-36199$ 
Yamamoto S, Tamai H, Ishisaka R, Kanno T, Arita K, Kobuchi H, Utsumi K (2000) Mechanism of $\alpha$-tocopheryl succinate-induced apoptosis of promyelocytic leukemia cells. Free Radical Res 33: 407-418

Yu W, Israel K, Liao QY, Aldaz M, Sanders BG, Kline K (1999) Vitamine E succinate (VES) induces Fas sensitivity in human breast cancer cells: Role for Mr 43,000 Fas in VES-triggered apoptosis. Cancer Res 59: 953-961

Yu W, Liao QY, Hantash FM, Sanders BG, Kline K (2001) Activation of extracellular signal-regulated kinase and c-Jun- $\mathrm{NH}_{2}$-terminal kinase but not p38 mitogen-activated protein kinases is required for $R R R-\alpha-$ tocopheryl succinate-induced apoptosis of human breast cancer cells. Cancer Res 61: 6569-6576

Yu W, Sanders BG, Kline K (2003) Tocopheryl succinate-induced apoptosis of human breast cancer cells involves Bax translocation to mitochondria. Cancer Res 63: 2483-2491

Zhang JG, Nicholls-Grzemski FA, Tirmenstein MA, Fariss MW (2001) Vitamin E succinate protects hepatocytes against the toxic effect of reactive oxygen species generated at mitochondrial complexes I and III by alkylating agents. Chem Biol Interaction 138: 267-284 